\title{
INVESTIGATION OF THE COMBINED EFFECT OF IONIZING RADIATION OF DIFFERENT QUALITY AND DOXORUBICIN ON BREAST ADENOCARCINOMA CELLS
}

\author{
L. N. Komarova, A. A. Melnikova*
}

Obninsk Institute for Nuclear Power Engineering, Obninsk, Russia

\begin{abstract}
The purpose of this work was to study the nature of the combined effect of ionizing radiation of accelerated ${ }_{12 C}$ ions with the antitumor agent doxorubicin on malignant cells. In the course of the research, new results were obtained on the manifestation of the synergistic character of the interaction of the agents used on the cells of the MCF-7 tumor line, which is of important practical and theoretical significance for understanding the mechanism of the combined effect of ionizing radiation and the chemotherapy drug doxorubicin. The obtained data will help to optimize the combined effects in order to achieve maximum synergistic interaction.
\end{abstract}

Key words: Doxorubicin, gamma radiation, hadron therapy, synergism, tumor cells

\section{INTRODUCTION}

Therapy with ${ }^{12} \mathrm{C}$ ions is the most effective and accurate method of radiation therapy for deep-seated and radioresistant tumors [1]. A significant advantage of radiation therapy is the penetration of a beam of accelerated ${ }^{12} \mathrm{C}$ ions to the required depth with maximum damage to tumor cells. At the end of the run, the carbon ions experience a sharp deceleration, transferring most of the energy to the absorbed substance (Bragg peak) [2]. Thus, there is a selective effect on the deep-seated tumor.

It is known that the combined effect of ionizing radiation and medicinal antitumor drugs can increases the radiosensitivity of tumor cells. As a result, it is relevant to study the combined effect of ionizing radiation and antitumor agent. Due to the wide spectrum of action against many types of tumors, we chose doxorubicin as a chemotherapy drug. The cytotoxic effect of doxorubicin is to suppress the synthesis of DNA and RNA mainly in the S-phase due to the formation of free radicals [3]. In the case of some tumors, it is possible to develop resistance to the drug. The solution to this problem can be a combination of various methods of therapy, which is used to increase the radiosensitivity of tumor cells in the treatment of resistant forms of malignant neoplasms of various localizations.

The purpose of our research work is to study the nature of the combined effect of ionizing radiation of accelerated ${ }^{12} \mathrm{C}$ ions with the antitumor agent doxorubicin on malignant cells.

\section{MATERIALS AND METHODS \\ 2.1. Cell culture}

The object of the study was the MCF-7 cell culture (human breast duct adenocarcinoma). The cells were cultured as a monolayer. Cell suspensions were prepared at a concentration of $\sim 5^{\times 10^{4}}$ cell $/ \mathrm{ml}$ to avoid hypoxic conditions [4]. The irradiation procedure was carried out in $1.5 \mathrm{ml}$ Eppendorf-type test tubes. The study identified three groups of research: Group 1 irradiation of tumor cells with gamma radiation and ${ }^{12} \mathrm{C}$ ions; group 2 - incubation of cell cultures with doxorubicin at a concentration of $0.004 \mathrm{mg} / \mathrm{ml}$; group 3 - the combined effect of doxorubicin and ionizing radiation. The control was unirradiated and untreated cells.

The procedure of irradiation of cell cultures was carried out on the U-70 carbon ion accelerator (Institute of High Energy Physics, Protvino). The irradiation was carried out in an aqueous phantom with an average energy of $450 \mathrm{MeV} /$ nucleon. The cells were irradiated on a beam of carbon ions in an unmodified Bragg peak (the LET in the Bragg peak was $120-140 \mathrm{keV} / \mu \mathrm{m}$ ). The source of the standard radiation was the gamma radiation irradiation unit "GUR-120 "(source of ionizing radiation ${ }^{60} \mathrm{Co}, \mathrm{E}=1.25 \mathrm{MeV}$ ). The dose rate is $0.9 \mathrm{G} / \mathrm{min}$. Radiation doses: 1, 2, 4, 6 Gy.

\subsection{Study of cell survival}

Cell survival was assessed by a colony-forming test, which allows us to assess the ability of a cell to form a colony. This technique is used to determine the effectiveness of radiation therapy and cytotoxic drugs $[5,6]$.

\subsection{Description of the registered effects}

The relative biological efficiency was determined by the equation [7]:

$$
R B E=\frac{D_{X}}{D_{R}}
$$

where $D_{x}$ - the absorbed dose required to obtain this biological effect when exposed to standard radiation (gamma radiation), and $\mathrm{D}_{\mathrm{R}}$ - the absorbed dose of the 
studied ionizing radiation necessary to obtain the same biological effect.

It is known that the sequential interaction of two agents can be synergistic or antagonistic in nature [8]. The recorded synergistic effect of the combined action of $12 \mathrm{C}$ ions and doxorubicin will reduce the doses of radiation and chemotherapy, thereby reducing the manifestations of side effects. The probability of a registered effect under an independent action, in accordance with the known position of probability theory, is determined by the product of the probabilities of effects induced by each agent separately. For cell survival, we have [8-10 ]:

$$
S=S_{1} \times S_{2},
$$

where $\mathrm{S}$ is the probability of cell survival after combined exposure, and $S_{1}$ and $S_{2}$ are the probabilities of survival after the action of each of the agents used separately.

The synergistic enhancement coefficient (synergism coefficient) is determined by the ratio of the doses obtained as a result of determining the theoretically expected cell survival with an independent addition of the effects of both agents (D1) to the corresponding survival estimated by the experimental survival curve obtained after the combined action (D2) [8-10]:

$$
k=\frac{D_{2}}{D_{1}}
$$

The coefficient of synergistic enhancement is determined by the ratio of the theoretically expected survival of a cell culture with an independent addition of the effects of both agents to the corresponding survival estimated from experimental data obtained after the combined action.

Statistical processing. To conduct a statistical analysis of the results of each experiment, data from three repetitions were used. Statistical data processing was carried out using the nonparametric Mann-Whitney criterion, reflecting the reliability of differences between the control and analyzed groups, at a significance level of $\mathrm{p}<0.05$.

\subsection{Statistical processing}

Data for three repeats were used for the statistical analysis of the results from each experiment. The results were processed statistically and the parameters of the dose-effect curves were determined using standard methods implemented in the Microsoft Excel tools using the nonparametric Mann-Whitney rank order test for the significance level $a=5 \%$. Differences with $\mathrm{p}<0.05$ were considered statistically significant.

\section{RESULTS}

At the initial stage of the study, a comparative assessment of the survival of cells after the action of ionizing radiation of different quality on them was carried out. Figure 1 shows a graph of the dependence of the survival rate of MCF-7 tumor cells on the radiation dose. Curve 1 in all the figures shows the effect of gamma radiation, curve 2-the effect of hadron radiation ${ }^{12} \mathrm{C}$.

The figure shows that under the action of ion radiation, the survival rate of tumor cells is lower than under the action of rare ionizing radiation. The index of the $\mathrm{RBE}$ of ion radiation of ${ }^{12} \mathrm{C}$ for the $\mathrm{MCF}-7$ cell line according to the equation (1) was $1.7 \pm 0.1$.

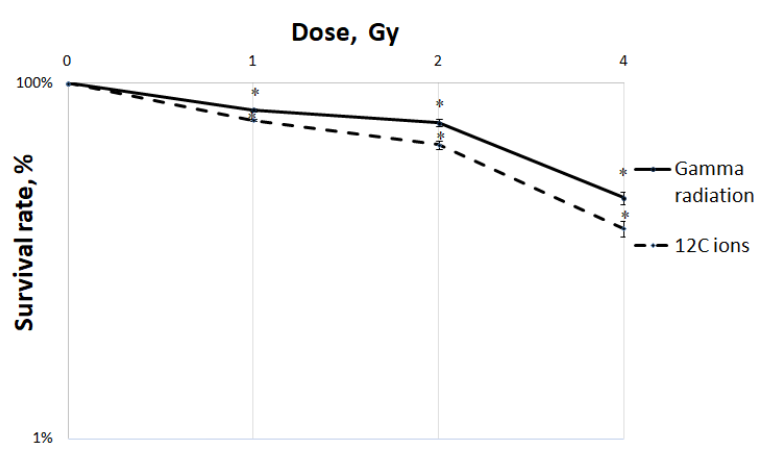

Figure 1. The dependence of the survival rate of MCF-7 cells on the dose of ionizing radiation (*- a significant difference from the control at $\mathrm{p}<0.05$ )

Previously, we obtained data in the study [11, 12], where cell survival is $7 \%$ under the combined action of dense ionizing radiation (carbon ions $12 \mathrm{C}$, energy $450 \mathrm{MeV}$ / nucleon) at a maximum dose of $4 \mathrm{~Gy}$ and doxorubicin.

Similarly to the previous experiment, we conducted studies of the regularity of the combined effect of rare ionizing radiation with doxorubicin.

Figure 2 shows the survival curves of malignant cells depending on the dose after the analysis for clonogenic activity. Curve 1 (Fig.1) is the curve of the dependence of cell survival after the action of ionizing radiation alone $\left({ }^{60} \mathrm{Co}, \mathrm{Ecp}=1.25 \mathrm{MeV}\right)$, the effect of doxorubicin alone is shown by point 2, curve 3 is the theoretical curve expected with an independent addition of the effects of ionizing radiation and the drug doxorubicin, curve 4 is the survival of cells after the combined action.

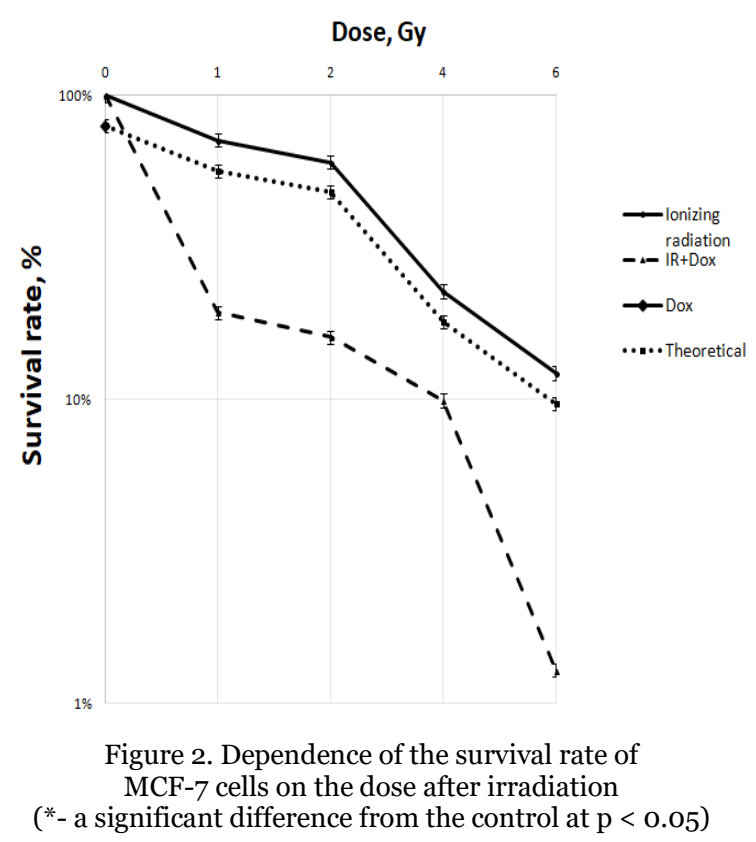


In this case, the interaction of the two agents is synergistic. In the case of the results obtained, at the initial stage (immediately after irradiation), the interaction of rare ionizing radiation and the drug makes the greatest contribution to the formation of damage not by the combined action of these factors, but by the action of doxorubicin. Since the formation of damage after exposure to radiation will be significantly less due to the short duration of simultaneous action of two agents.

Figure 3 shows the indicators of $\mathrm{k}$ (see Equation 3 ) corresponding to the 50\% survival rate and higher, as well as the level observed with a survival rate of less than $50 \%$.

Taking into account the results obtained when constructing the survival curves in Figure 2, the dependence of the synergistic gain coefficient on the dose was calculated (see Figure 3).

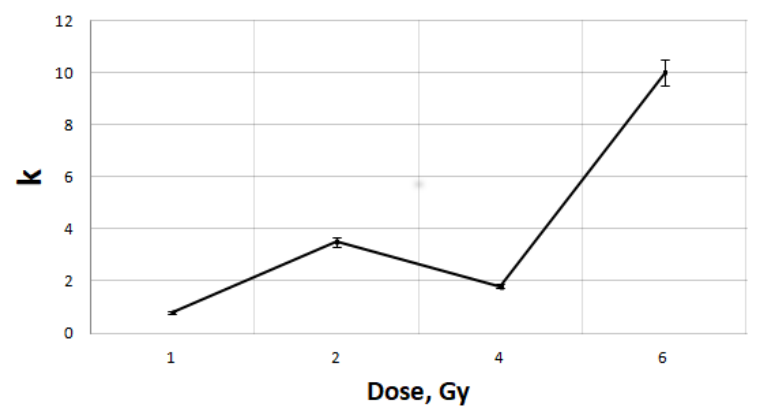

Figure 3. The dependence of the synergistic gain coefficient on the dose

Our results show that the synergistic effect manifests itself with an increase in the dose of rare ionizing radiation. The maximum synergistic effect is observed at a dose of $6 \mathrm{~Gy}$ and is equal to 10. According to the mathematical model of synergy, the maximum interaction is achieved when the sub-damages that form each of the studied factors (ionizing radiation and doxorubicin) are equal.

\section{CONCLUSION}

As part of the experimental work, some regularities of the synergistic interaction of dense and rare ionizing radiation with doxorubicin on human tumor cell cultures were revealed. The relative biological effectiveness of the action of $12 \mathrm{C}$ ions with a single irradiation on tumor cells of the $\mathrm{MCF}-7$ line was established, the OBE values were 1.7. With the combined action of $12 \mathrm{C}$ ions and doxorubicin, a synergistic interaction of two factors is observed. A long doubling time, low cell survival indicates irreversible damage, which the cell cannot eliminate.

\section{REFERENCES}

1. С. И. Ткачев, М. И. Нечушкин, Т. В. Юрьева, "Современные возможности лучевой терапии злокачественных опухолей,” Вестник РАMH но. 12, стр. 34-40, 2011.
(S. I. Tkachev, M. I. Nechushkin, T. V. Yuryeva, "Modern possibilities of radiation therapy of malignant tumors," Bull. of the Russian Academy of Medical Sciences, no. 12 , pp. $34-40,2011$.)

2. Д. В. Лосев, М. Ф. Ломанов, А. П. Черняев, "Аналитический расчет модифицированной кривой Брэгга,” Препринт НИИЯФ МГУ, но. 16, 2003.

(D. V. Losev, M. F. Lomanov, A. P. Chernyaev, "Analytical calculation of the modified Bragg curve," Preprint of the Moscow State University Research Institute of Nuclear Physics, no. 16, 2003.)

3. Н. И. Переводчиковой, Руководство по химиотерапии опухолевых заболеваний, Москва: Практическая Медицина, 2011.

(N. I. Perevodchikova, Guide to chemotherapy of tumor diseases, Moscow: Practical Medicine, 2011.)

4. F. J. Rini, E. J. Hall, S. A. Marino, "The oxygen enhancement ratio as a function of neutron energy with mammalian cells in culture," Radiat. Res., vol. 78, no. 1 , pp. 25-37, 1979. https://doi.org/10.2307/3575004

5. D. A. Kasatov et al., "Radiation at absorption of $2 \mathrm{MeV}$ of protons in various materials," Nuclear Physics, vol. 78, no. 11, pp. 963-969, 2015.

6. L. A. Mostovich et al., "Influence the epithermal neutrons on viability of tumor cells of glioblastoma of in vitro," Bull. Exper. Biology and Medicine, vol. 151, no. 2, pp. 229-235, 2011.

7. С. П. Ярмоненко, А. А. Вайнсон, Радиобиология человека и животных, Москва: Высшая школа, 2004

(S. P. Yarmonenko, A. A. Vainson, Radiobiology of Humans and Animals, Moscow: Vysshaya shkola, 2004.)

8. В. Г. Петин, Г. П. Жураковская, Л. Н. Комарова, Радиобиологические основы синергетических взаимодействий в биосфере, Москва: ГЕОС, 2012. (V. G. Petin, G. P. Zhurakovskaya, L. N. Komarova, Radiobiological bases of synergistic interactions in the biosphere, Moscow: GEOS, 2012.)

9. Г. П. Жураковская, В. Г. Петин, “Принципы математического моделирования комбинированных воздействий в биологии и медицине (обзор литературы),” Радиация и Риск, т. 24, но. 1, стр. 61-73, 2015.

(G. P. Zhurakovskaya, V. G. Petin "Principles of mathematical modeling of combined effects in biology and medicine (literature review)," Radiation and Risk vol. 24, no. 1, pp. 61-73, 2015.)

10. С. В. Белкина, Л. Н. Комарова, Р. О. Крицкий, "Прогнозирование синергических эффектов ионизирующего излучения и других повреждающих факторов на клетки млекопитающих и растения)," Радиация и риск, т. 15, но. 3-4, стр. 120-132, 2006. (S. V. Belkina, L. N. Komarova, R. O. Kritsky, "Prediction of synergistic effects of ionizing radiation and other damaging factors on mammalian and plant cells)," Radiation and Risk, vol. 15, no. 3-4, pp. 120-132, 2006.)

11. Л. Н. Комарова, А. А. Мельникова, Д. А. Балдов, "Исследование комбинированного действия ионизирующего излучения и доксорубицина на клетках аденокарциномы молочной железы человека MCF-7," Научные междисциллинарные исследования. Материалы ХІІІ Международной научно-практической конференции, "КДУ", “Добросвет", стр. 14-22, 2021.

(L. N. Komarova, A. A. Melnikova, D. A. Baldov, "Study of the combined effect of ionizing radiation and doxorubicin on human breast adenocarcinoma cells MCF-7," in Scientific interdisciplinary research. Materials of the XIII International Scientific and Practical Conference, "KDU", "Dobrosvet", pp. 14-22, 2021.)

https://doi.org/10.31453/kdu.ru.978-5-7913-1172-62021-14-21 
L.N. Komarova, A.A. Melnikova, Effect of ionizing radiation and doxorubicin, RAD Conf. Proc., vol. 5, 2021, 100-103

12. A. Melnikova, L. Komarova, "Research on the combined effects of radiation and chemotherapy on tumor cells," in Book of Abstr. $9^{\text {th }}$ Int. Conf. on Radiation in Various
Fields of Research (RAD 2021), Herceg Novi, Montenegro, 2021, p. 228.

https://doi.org/10.21175/rad.abstr.book.2021.32.6 